\title{
OBITUARY
}

\section{DAVID STORM RICE}

On 19 April 1962, his many friends heard with sadness of the death of Storm Rice.

I first met Storm in the summer of 1943 in the parlour of a hot and dusty villa in Cyrenaica. He was interrogating a Senussi Arab, a surly fellow crouching on the floor in his soiled jird. Storm seated himself beside him, and spoke to the old man in Arabic. And as he spoke and questioned and cajoled, the expression on the Arab's face changed rapidly from suspicion to surprise, from surprise to admiration. A quip, a flash of repartee, patient silence while the old man gathered his thoughts - without warning, a sharp inquiry--and Storm had learnt all that he required. The old man was dismissed with a friendly wave ; Storm turned to record on his files with care and detail all the information which he had obtained with such apparent ease. The incident was significant. It was this remarkable combination of the imagination and humanism of the artist with the meticulous accuracy of the scholar that distinguished Storm Rice among his colleagues.

Sigismund--to his family and friends Susya-Reich was born at Schönbrunn, Austria, on 28 March 1913. At the age of ten he migrated to Haifa, Palestine, with his parents. His father was a surveyor and engineer, a tall bearded figure who is still remembered in Israel with affection. He was a man of vision, and his enterprise bore tangible fruit in schemes of settlement at Nahariya and on the outskirts of Haifa itself. But the son-then an only child-showed little bent for the exact sciences. Even in later years he was easily perplexed by simple mathematical calculations, and the mechanism of an engine was something to be mastered rather than to be enjoyed. He was educated at the Reali School at Haifa; his fellow-pupils recall him as a dreamy boy, who spent many hours in vicarious adventure at the cinema.

In 1931 he left Palestine for Europe, on his own quest for adventure-a quest that ended only with his death. From 1931 to 1932 he studied at the Royal Academy of Fine Arts at Florence. In 1932 he commenced studies in Arabic, philology, anthropology, and the history of religion at the Ecole Nationale des Langues Orientales Vivantes, the Sorbonne, and the École Pratique des Hautes Études of the Collège de France at Paris, receiving the Licence ès-Lettres in 1935. During these years life was not easy, since he had to support himself financially; but the impecunious student developed a resourcefulness that was to stand him in good stead in later years. He formed friendships which he retained throughout his life. Most important, he came under the influence of some of the giants of contemporary Orientalism—notably Dhorme, GaudefroyDemombynes, W. Marçais, Massignon, and Sauvaget. To them he owed his passion for lucidity of thought, and for vividness of presentation and ease of expression. The thesis for which he obtained the title of Docteur de l'Université 


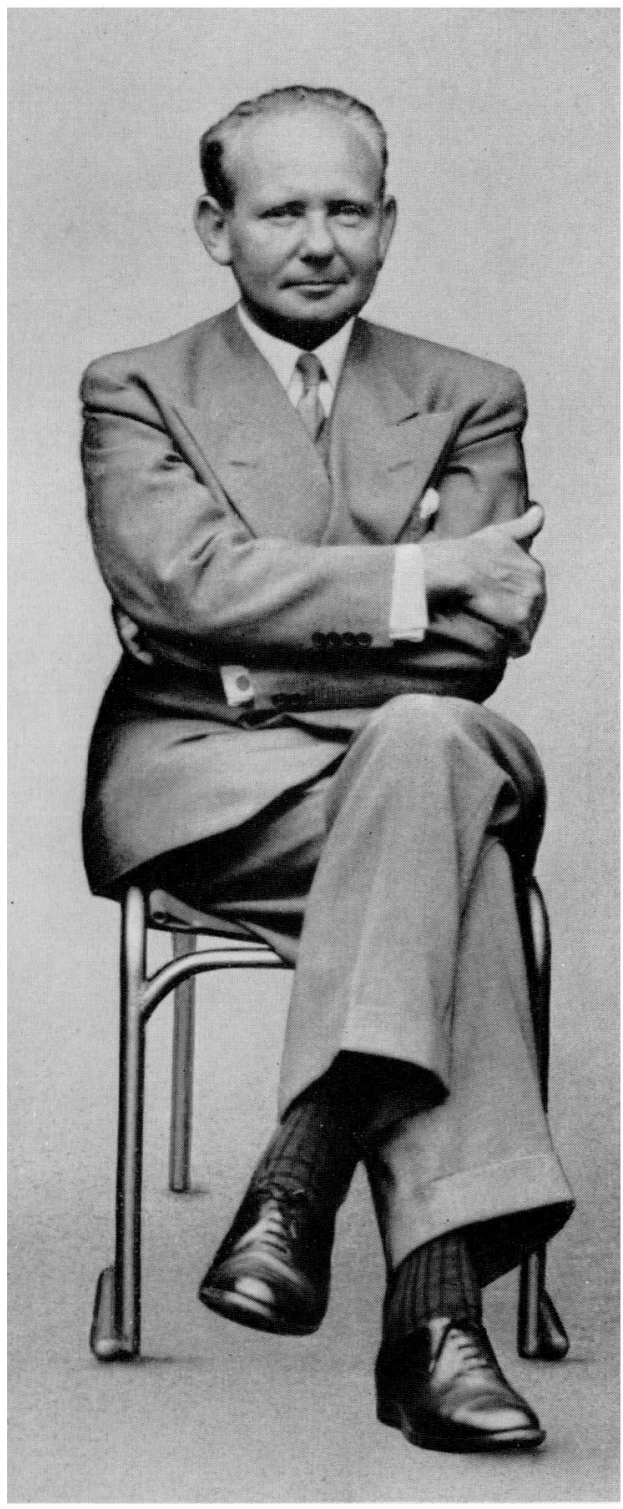

David Storm Rice

BSOAS. XXY] 
de Paris in 1937 was a study of the Aramaic-speaking communities in the neighbourhood of Damascus. This book, published by the French Institute at Damascus, is a volume of rare quality. It comprises a number of texts, transliterated with exactness. They are of ethnographic interest, and around them Reich assembled data on the historical, geographical, economic, and social background of these isolated villages. His description of churches and mosques and dwelling-places, of the occupations of the villagers, and their domestic habits is written with delicacy and assurance; and the volume is illustrated by photographs and drawings of remarkable skill.

In the course of his wide travels in the Near East at this period, Reich had come into intimate association with L. A. Mayer, and with Ralph Harari and Wiet at Cairo. It was largely under their influence that he developed his interest in Islamic art. But it was also in accord with his natural bent. He was, indeed, happiest in these studies, which exercised amply both his artistic and his linguistic talent.

By 1939, with the outbreak of war, Reich was already a Semitist of outstanding promise. He had acquired an international reputation by his book, by articles, and by contributions to the Répertoire d'épigraphie arabe. World events now introduced him to a different sphere of activity. In the early stages of the war he volunteered for the British Army. His ability won for him rapid promotion; by 1943 he was already a Major in charge of an Intelligence unit in Eritrea. After spells of duty in Cyrenaica and Egypt, he was transferred to Italy and Germany, and he performed important services in the Control Commission in Germany when active hostilities had ended. The war years were for him a period of enthralling interest, in which his love of adventure, his lively imagination, and his energy had full play. He was not always an easy colleague, because he had little patience for mediocrity and his tongue did not spare the inefficient. But, working alongside the British, he conceived an admiration for the finer qualities of Britain and the British that never left him. It was at this time that he formally adopted the names by which he was best known. They were a deliberate choice, chosen with a happy amalgam of the practical, the witty, and the romantic--Rice because that was, he asserted, the manner in which his surname Reich was pronounced by some Englishmen, Storm because this was suggested by the initials of his forenames (S. S.), and David because he regarded the poet-king as the most attractive and human figure of the Bible. Rice now received British nationality; the citizen of the world had become citizen of an adoptive country.

During the war Rice had had little time for scholarly work. In 1947 he returned to academic life, joining the staff of SOAS as Lecturer in Near and Middle Eastern History. Recognition of his special interests came in 1950 with his appointment to a newly-created Readership in Islamic Art and Archaeology in the University of London; in 1959 he was given the title of Professor. It is not required of a Reader or Professor that he should be expert in the whole range of studies covered by his title, but Rice saw here a challenge to be met. 
There was no aspect of the vast field of Islamic art and Islamic archaeology on which he could not write and talk with a clarity and an enthusiasm that were always informative and never tedious-and, it should be recalled, in a language which was not his native tongue. His written contributions to the study of Islamic art were a model of logical exposition, illustrated by brilliant photographs and drawings that were the product of long and wearying labour. His gifts as epigraphist enabled him to decipher involved Arabic inscriptions and to unravel complex artistic motifs. To the layman as to the expert, his writings were of absorbing interest in the dexterity of his approach to a problem and his sensitive appreciation of the factors that lay behind it. His monographs on the so-called Baptistère de Saint Louis and on the Wade Cup are the work of a master of his craft, and the volume on the Ibn al-Bawwäb manuscript of the Qur'ān is worthy of its unique subject. Among his articles we may single out the six 'Studies in Islamic metal work' as displaying Rice's talent to the full. The detailed analysis of individual pieces of work owes its success to the sympathy which Rice, as an artist and craftsman, had for his fellowartists and craftsmen centuries earlier. Each article is a vignette-rich, stimulating, and varied - of life under medieval Islam.

Rice's contribution to the study of Islamic archaeology was little less fruitful, though here he seems to have felt less at ease. His field-work was carried out principally in Turkey. He collaborated with Seton Lloyd in a volume on Alanya ; and he made several tours both to the west and the east of the Euphrates, where his quick eye and agile mind left a vivid impression on local officials - and on ordinary folk-from Ankara to Diyarbakir. It was, however, for his work at Harran that he achieved fame in the world of archaeology. In the course of several seasons between 1951 and 1959 he excavated the area of the Great Mosque and carried out preliminary excavations by the Citadel and beyond the Mosque. The impact that this work, successfully completed, might have had upon our knowledge of the ancient, as well as the medieval, world may be gauged by the importance of the Nabonidus stelae which he found in 1956. Rice was devoted to Harran. He had studied every phase of its history; he loved even the barren, modern village against the summer sunset. At excavations he was an irascible and exacting employer. But he never spared himself, and 'ar-Rais' was respected by the simple villagers of Harran.

Teachers of art and archaeology are isolated and vulnerable in an age where immediate tangible results are too often the measuring-rod of success. In his field of study Rice was especially isolated. He refused to compromise with the shoddy and insincere. And while he prosecuted his researches with boldness and initiative, he found it not easy to set down their results in writing; this is the penalty that is paid by many a perfectionist. Comparatively little, then, of his vast and ever-widening erudition-the product of journeys in Russia, U.S.A., France, Italy, North Africa, Turkey, and, most recently, Spain-was published. The survey of the Tektek mountains (especially the inscriptions of Shueib Shahr) which he carried out in 1956, the application to Arabic epigraphy 
of new methods of systematic classification which he had analysed during the last two years, his treatise on the cheetah in literature and in art, and, most of all, the definitive account of work at his beloved Harran-little of this has appeared in print. It is to be hoped that at least some of the essays and notes which will be found among his thousands of photographs and drawings may be edited and prepared for publication.

Rice's restless energy found many outlets. He took a full part in the everyday life of SOAS, he attended meetings of Boards of Studies and of the Academic Board. He was proud to have been elected a member of the Governing Body of SOAS in 1961. He was an active member of the Royal Asiatic Society, he devoted much time to the affairs of the British Institute of Archaeology at Ankara, and he was a founding member of the new British School at Tehran. He became a Fellow of the Society of Antiquaries in 1952, and he was awarded the D.Lit. of the University of London in 1957. In social contacts his charm and vivacity were unflagging. He was at his happiest in entertaining his friends and students (whom he numbered among his friends), both from this country and from abroad, with the kaleidoscopic vividness of his conversation. $\mathrm{He}$ lectured widely to learned societies and to schools. The circle of his correspondents extended through many countries.

Those who were near to Storm during the last weeks of his illness had thought that he was likely to recover. They admired the gallantry with which he began to return to his former associates, his club, and his friends ; it was the same carefree sang-froid that he had displayed when his hotel at Tripoli was bombed during the war, or when his Landrover overturned on the highway to Adana and he survived only by a miracle. But the constant stress to which his physical powers had been subjected proved too great. Nevertheless, he maintained to the end his affection and enthusiasm for his friends and his work. We are sadly the poorer by his death, but we are grateful for what he gave us- the inspiration of his humanism and generosity and boundless vitality.

J. B. SEGAL

\section{PROFESSOR D. S. RICE-BIBLIOGRAPHY ${ }^{1}$}

Notes archéologiques sur Médine. Revue des Études Islamiques, x, 1, 1936, 105-12.

Communication. In É. Combe and others (ed.): Répertoire chronologique d'épigraphie arabe, publié ... sous la direction de Ét. Combe, $J$. Sauvaget et $G$. Wiet. (Publications de l'Institut Français d'Archéologie Orientale.) Le Caire : Imprimerie de l'Institut Français d'Archéologie Orientale, vin, 1937, No. 2947A, p. 295.

Communication. In É. Combe and others (ed.): Répertoire chronologique d'épigraphie arabe, IX, 1937, No. 3252, pp. 34-5.

Études sur les villages araméens de l'Anti-Liban. (Documents d'Études Orientales de l'Institut Français de Damas, Tom. vII.) [Damas : Institut Français de Damas, 1937.] xv, 196 pp., 32 plates.

Quatre coupes magiques. Bulletin d'Études Orientales, vII-viI, 1937-8, [pub.] 1938, 159-75.

1 Publications by Professor Rice which appeared between 1936 and 1943 were signed

' $S$. Reich'. Reviews have not been included. 
Un astrolabe syrien du xrve siècle. [In collaboration with G. Wiet.] Bulletin de l'Institut Français d'Archéologie Orientale, xxxviII, 1939, 195-202.

Une insoription mamlonke sur un dessin italien du quinzième siècle. Bulletin de l'Institut d' Égypte, XXII, 1939-40, [pub.] 1940, 123-31.

Communication. In É. Combe and others (ed.): Répertoire chronologique d'épigraphie arabe, XII, 1943, No. 4685, p. 190.

Le 'Baptistère de Saint-Louis'. In Actes du XXI e Congrès International des Orientalistes, Paris, 23-31 juillet 1948. Paris : Société Asiatique de Paris, 1949, 325-6.

The oldest dated 'Mosul' candlestick, A.D. 1225. Burlington Magazine, XCI, 561, 1949, 334-40.

The blazons of the 'Baptistère de Saint Louis'. BSOAS, xIIr, 2, 1950, 367-80.

The brasses of Badr al-din Lu'lu'. BSOAS, xIII, 3, 1950, 627-34.

Le Baptistère de Saint Louis. Paris : Les Éditions du Chêne, 1951. 31 pp., 40 plates.

Bibliography of contributions on Islamic art published in Germany and Austria during the war years, 1939-1945. Ars Islamica, Xv-XvI, 1951, 151-3.

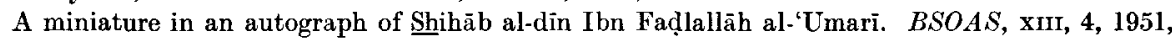
856-67.

Medieval Harrān. Studies on its topography and monuments, I. Anatolian Studies, II, 1952, $36-84$.

Studies in Islamic metal work [-I]. BSOAS, xIv, 3, 1952, 564-78.

Unique dog sculptures of mediaeval Islam : recent discoveries in the ancient Mesopotamian city of Harran and light on the little-known Numairid dynasty. Illustrated London News, cCXXI, 20 September 1952, 466-7.

The Aghănì miniatures and religious painting in Islam. Burlington Magazine, xcv, 601, 1953, 128-34.

The Baptistère de Saint Louis. [English edition.] Paris : Les Éditions du Chêne, 1953. 31 pp., 40 plates.

Seeking the temple of Sin, moon-god of Harran, and light on the strange Sabian sect through 1400 years. [In collaboration with Seton Lloyd.] Illustrated London News, ccxxII, 21 February 1953, 286-9.

Studies in Islamic metal work-II. BSOAS, xv, 1, 1953, $61-79$.

Studies in Islamic metal work-III. $B S O A S, \mathrm{xv}, 2,1953,229-38$.

Studies in Islamic metal work-IV. BSOAS, xv, 3, 1953, 489-503.

Alanya. [Provisional report on the inscriptions.] Anatolian Studies, iv, 1954, 13-14.

The seasons and the labors of the months in Islamic art. Ars Orientalis, I, 1954, 1-39.

Studies in Islamic metal work-V. BSOAS, xvII, 2, 1955, 206-31.

A Muslim shrine at Hiarrān. BSOAS, xviI, 3, 195̃5, 436-48.

The unique Ibn al-Bawwäb manuscript in the Chester Beatty Library. Dublin : Emery Walker, 1955. [v], 37 pp., 16 plates.

The Wade Cup in the Cleveland Museum of Art. Paris : Les Éditions du Chêne, 1955. 39 pp., 20 plates.

Arabic inscriptions on a brass basin made for Hugh IV de Lusignan. In Studi orientalistici in onore di Giorgio Levi della Vida. (Pubblicazioni dell'Istituto per l'Oriente, Nr. 52.) Roma : Istituto per l'Oriente, 1956, II, 390-402.

A datable Islamic rock crystal. Oriental Art, New Series, п, 3, 1956, 85-93.

Islamic art and archaeology : a register of work published in the year 1954. [In collaboration with J. D. Pearson.] Cambridge : W. Heffer and Sons Ltd., 1956. [ii], iii, 38 pp.

From Sin to Saladin : excavations in Harran's Great Mosque, with new light on the Babylonian king Nabonidus and his 104-year-old mother. Illustrated London News, ccxxxI, 21 September 1957, 466-9.

Inlaid brasses from the workshop of Ahmad al-Dhakī al-Mawșilī. Ars Orientalis, II, 1957, 283-326.

Two unusual Mamlūk metal works. BSOAS, xx, 1957, 487-500.

Alanya ('Alä'iyya). [In collaboration with Seton Lloyd.] (Occasional Publications of the British Institute of Archaeology at Ankara, No. 4.) London : The British Institute of Archaeology at Ankara, 1958. viii, $70 \mathrm{pp}$., front., 16 plates.

Deacon or drink : some paintings from Samarra re-examined. Arabica, v, 1, 1958, 15-33.

A drawing of the Fatimid period. BSOAS, xxI, 1, 1958, 31-39.

Early signed Islamic glass. JRAS, 1958, 1-2, pp. 8-16.

Studies in Islamic metal work-VI. BSOAS, xxI, 2, 1958, 225-53. 
The Fermo chasuble of St. Thomas-a-Becket-revealed as the earliest fully dated and localised major Islamic embroidery known. Illustrated London News, Ccxxxv, 3 October 1959, $356-8$.

The oldest illustrated Arabic manuscript. BSOAS, x xII, 2, 1959, 207-20.

Islamic art and archaeology : a register of work published in the year 1955. [In collaboration with J. D. Pearson.] Cambridge : W. Heffer and Sons Ltd., 1960. [ii], iii, 65 pp.

Leo A. Mayer (in memoriam). Ars Orientalis, rv, 1961, 454-5. 